\title{
CHROMOSOME MOSAICS IN EXPERIMENTAL AMPHIPLOIDS IN THE TRITICINAE
}

\author{
LEO SACHS \\ Plant Breeding Institute, Cambridge, \\ John Innes Horticultural Institution, Bayfordbury, Hertford, Herts.

\section{CONTENTS}

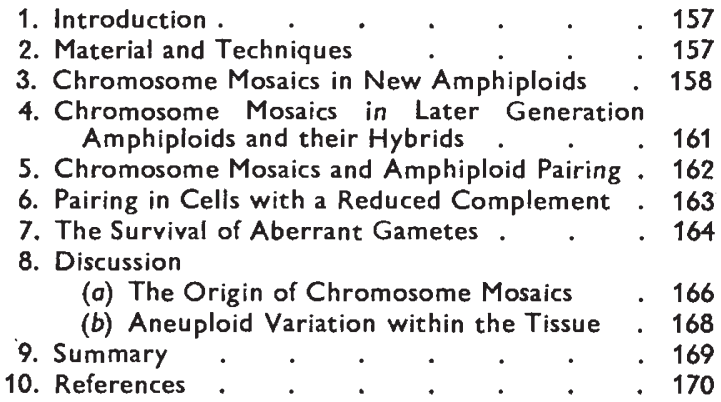

\section{INTRODUCTION}

DURING the course of an investigation on a series of experimental amphiploids, it was found that different chromosome numbers can occur in the same anther, with up to 27 chromosome numbers in the same plant. Cells with the different chromosome numbers were able to undergo meiosis, and in some cases form functional gametes. These gametes can then produce various chromosome number segregates from the same amphiploid parent. It was therefore decided to study the occurrence and distribution of chromosome variation in different plants and chromosome variation in the same plant. The present study describes these variations in a range of amphiploids involving Triticum, Aegilops, and Agropyron, three genera belonging to the subtribe Triticinae.

The anthers with different chromosome numbers contain at meiosis a mixture of cells with complete amphiploid and various reduced aneuploid chromosome complements. After the terminology of Fankhauser (1945) these tissues with different numbers can thus be described as "complex chromosome mosaics".

\section{MATERIAL AND TECHNIQUES}

The following species have been used in the production of those amphiploids and amphiploid hybrids which have been studied.

$$
2 n=14
$$

Aeg. bicornis (Forsk.) Jaub and Sp.

Aeg. caudata L.

Aeg. squarrosa L.

Aeg. umbellulata Zhuk.

Aeg. cylindrica Host.

$$
2 n=28
$$

Aeg. ovata L.

T. timopheevi Zhuk.

T. dicoccoides Körn. 
T. boeticum (Boiss.) Schiem.

T. dicoccum Schübl.

( $=\mathcal{T}$. aegilopoides (Link.) Bal.)

T. durum Desf.

T. turgidum L.

$$
2 n=42
$$

T. polonicum $\mathrm{L}$.

Agr. intermedium (Host.) Beauv.

T. aestivum L.

$$
(=\mathcal{T} \text {. vulgare Vill. })
$$

T. turanicum Jacub.

T. carthlicum Nevski

$$
(=\mathcal{T} \text {. orientale Perc. })
$$

$$
\text { (=T } \text {. persicum Vav.) }
$$

In the new amphiploids, $\mathcal{T}$. dicoccoides from three different sources will be referred to as $\mathcal{T}$. dicoccoides (a), (b) and (c).

Seeds of most of the new amphiploids were placed at my disposal by Dr G. D. H. Bell, and seeds of the later generation amphiploids were obtained from Dr E. R. Sears. All amphiploids were produced after colchicine treatment of $F_{1}$ hybrid plants.

For cytological observations, preliminary examinations of the anthers were made on temporary aceto-carmine smears. Permanent preparations of anthers were made by means of Feulgen squashes (Sachs, 1952). Root tip examinations were also made

\begin{tabular}{|c|c|c|c|c|c|}
\hline \multicolumn{2}{|c|}{ NEW AMPHIPLOIDS } & \multirow[t]{2}{*}{$2 n$} & \multirow{2}{*}{$\begin{array}{c}\begin{array}{c}\text { No. of } \\
\text { plants } \\
\text { examined }\end{array} \\
\text { I }\end{array}$} & \multirow{2}{*}{$\frac{\begin{array}{c}\text { No. of } \\
\text { cells } \\
\text { examined }\end{array}}{162}$} & \multirow{2}{*}{$\begin{array}{l}\begin{array}{c}\text { Cells with } \\
\text { reduced chromo- } \\
\text { some nos. } \%\end{array} \\
0.6\end{array}$} \\
\hline Aeg. ovata & $\times T$. timopheevi $(\mathrm{i})$ & & & & \\
\hline T. timopheevi & $\times T$. durum & 55 & I & I 32 & 0.8 \\
\hline T. dicoccum & $\times T$. timopheevi $(\mathrm{i})$ & 57 & I & $6 \times 3$ & $I \cdot I$ \\
\hline Aeg. cylindrica & $\times T$. carthlicum & $5^{6}$ & I & $34 i$ & $I \cdot 2$ \\
\hline$T$. dicoccum & $\times T$. timopheevi (ii) & .55 & I & 647 & $I \cdot 2$ \\
\hline,, & $\times$ Aeg. ovata & & 2 & 318 & $1 \cdot 9$ \\
\hline Aeg. cylindrica & $\times T \cdot$ durum & & 3 & 764 & $2 \cdot 1$ \\
\hline " & $\times T$. dicoccum & $\{55$ & 2 & 609 & $2 \cdot 1$ \\
\hline & $\times T$. carthlicum & $\begin{array}{l}34 \\
55\end{array}$ & I & 500 & $2 \cdot 4$ \\
\hline T. dicoccum & $\times T$. timopheevi (iii) & 56 & 2 & 979 & $2 \cdot 5$ \\
\hline T. timopheevi & $\times T$. turgidum & 56 & I & 503 & $2 \cdot 6$ \\
\hline Aeg. ovata & $\times T \cdot$ dicoccum & 5.5 & I & 782 & $2 \cdot 7$ \\
\hline T. dicoccoides (b) & $\times T$. timopheevi & $\begin{cases}55 & \\
& 56\end{cases}$ & 1 & $\begin{array}{r}341 \\
\text { I } 124\end{array}$ & $\begin{array}{l}2 \cdot 9 \\
3.4\end{array}$ \\
\hline T. dicoccoides (a) & $x$ & 56 & 3 & 1121 & $\begin{array}{l}3.4 \\
3.8\end{array}$ \\
\hline$T$. dicoccum & $\times$ Aeg. ovata & 55 & I & 323 & $4 \cdot 0$ \\
\hline T. timopheevi & $\times \Gamma$ durum & $5^{6}$ & 2 & $3 \times 2$ & $4 \cdot 8$ \\
\hline T. dicoccoides (a) & $\times$ Aeg. ovata & $5^{6}$ & 4 & 1179 & $6 \cdot 9$ \\
\hline$T$. diccocoides (c) & $\times \quad, \quad, \quad$ (i) & 55 & I & 538 & $7: 3$ \\
\hline Aeg. ovata & $\times T$. dicoccum & & 3 & $9^{3} \mathrm{I}$ & $8 \cdot 9$ \\
\hline n. & $\times$ T. timopheevi (ii) & $5^{6}$ & 3 & 609 & $I 4 \cdot I$ \\
\hline$T$. dicoccoides $(\mathbf{c})$ & $\times$ Aeg. ovata (ii) & 56 & 3 & 353 & $14 \cdot 5$ \\
\hline
\end{tabular}
on Feulgen squashes.

\section{TABLE I}

The Frequency of Mosaics at $M_{1}$ of Meiosis in $8 x$ Amphiploids

\section{CHROMOSOME MOSAICS IN NEW AMPHIPLOIDS}

With the exception of the rox $T$. dicoccum $\times A g r$. intermedium, all cytological observations on new amphiploids were made on first generation amphiploid plants. The amphiploid $T$. dicoccum $\times$ Aeg. caudata was grown in 1949 from the sced obtained after colchicine treatment of the $\mathrm{F}_{1}$ hybrids in $194^{8}$ All other first generation amphiploids were grown in the same glasshouse in $195^{\circ}$ from the seed obtained after colchicine treatment of the $F_{1}$ hybrids in 1949 . 'The rox amphiploid 
T. dicoccum $\times$ Agr. intermedium was studied in $195^{\circ}$ on a chromosome doubled part of the actual colchicine treated $F_{1}$ hybrid plants.

Chromosome counts at meiosis were made on anthers at the first metaphase $\left(\mathbf{M}_{\mathbf{1}}\right)$ and the figures in the tables were obtained from Feulgen squashes. In the mosaic plants different anthers from the same plant gave significantly different frequencies of cells with aberrant chromosome numbers. Thus an analysis of variance test on different anthers of the same plant, in several amphiploids, gave significant values for heterogeneity. This variation was also found in different plants of the same amphiploid. There was thus a variation in the percentage of cells with aberrant chromosome numbers, both in different anthers of the same plant, and in different plants of the same amphiploid. This variation is probably due to the environment. The percentages of reduced cells in plants with chromosome mosaics must therefore be considered relative rather than absolute.

In plants with mosaics the majority of cells still contain one chromosome number, the other cells at meiosis containing a lower chromosome number. This majority number is thus referred to as the chromosome number of the plant. The observed frequencies of mosaics at $\mathbf{M}_{\mathbf{1}}$ of meiosis is shown in table I for 54-57 chromosome plants, and in table 2 for 4 I-42 chromosome plants. 37 different reduced chromosome numbers, ranging from 9 to 48 , have been found in the amphiploids in table 1 , with up to 29 different numbers in the same amphiploid and 27 different numbers in a single plant of $T$. dicoccoides $(a) \times$ Aeg. ovata. 23 different reduced chromosome numbers, ranging from io to 40 , have been found in the new amphiploids in table 2 , with up to 15 different numbers in the same amphiploid and ro different numbers in a single plant of Aeg. ovata $\times T$. boeticum.

Chromosome mosaics at meiosis were however not found in 5 new amphiploids which were examined. Thus there were no mosaics in the following:

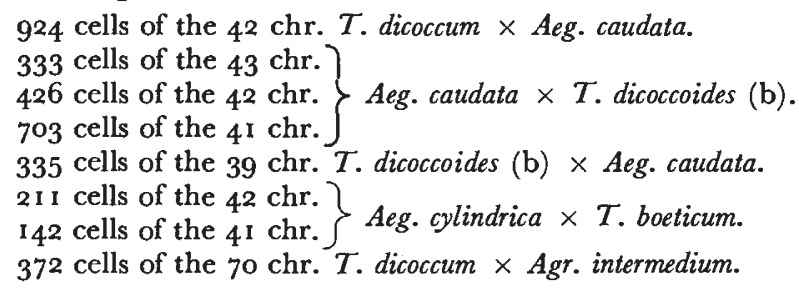

A comparison of the amphiploids shows that the presence of mosaics is dependent upon the particular parent species used in the production of the amphiploid. Thus e.g., the $T$. boeticum amphiploids gave mosaics if they included Aeg. ovata but no mosaics if they included Aeg. cylindrica.

The distribution of cells with different reduced chromosome numbers is shown in fig. I. Data for later generation amphiploids and amphiploid hybrids have been included in the diagram for the $6 x$ amphiploids. The diagram of the totals of reduced cells shows certain peak frequencies, such as the 42 and 35 chromosome peaks in the $8 x$ 
TABLE 2

The Frequency of Mosaics at $M_{1}$ of Meiosis in $6 x$ Amphiploids

\begin{tabular}{|c|c|c|c|c|c|}
\hline \multicolumn{2}{|c|}{ NEW AMPHIPLOIDS } & $2 n$ & $\begin{array}{l}\text { No. of } \\
\text { plants } \\
\text { examined }\end{array}$ & $\begin{array}{l}\text { No. of } \\
\text { cells }\end{array}$ & $\begin{array}{l}\text { Cells with } \\
\text { reduced chromo- }\end{array}$ \\
\hline \multirow{7}{*}{$\begin{array}{l}\text { Aeg. caudata } \\
\text { T. dicoccoides (c) } \\
\text { Aeg. caudata } \\
\text { T. dicocoides (c) } \\
\text { Aeg. caudata } \\
\text { Aeg. ovatia }\end{array}$} & $\times T$. dicoccum & $\left\{4^{2}\right.$ & 3 & 2639 & $\begin{array}{c}O \cdot I \\
0 \cdot I\end{array}$ \\
\hline & $\times \mathcal{T}$. turgidum & $4^{2}$ & 4 & 2520 & $0 \cdot t$ \\
\hline & $\therefore T$. boeticum & $4^{I}$ & I & 739 & 0.3 \\
\hline & T. durum & $4^{2}$ & 3 & I 106 & $0 \cdot 7$ \\
\hline & $\times T$, boeticum & $4^{2}$ & 3 & $123^{8}$ & $1 \cdot 5$ \\
\hline & $\times$ T. timopheri $i$ & $4^{2}$ & 4 & 689 & $3 \cdot x$ \\
\hline & $\times T$. boeticum & $4^{2}$ & 4 & 8.6 & $3 \cdot 2$ \\
\hline \multicolumn{2}{|c|}{$\begin{array}{c}\text { LATER GENERATION } \\
\text { AMPHIPLOIDS }\end{array}$} & & & & \\
\hline \multirow{2}{*}{$\begin{array}{l}\text { T. dicoccoides } \\
\text { T. timopheevi: }\end{array}$} & $\times$ Aeg. umbellulata & $4^{2}$ & I & $24 \mathrm{I}$ & 0.8 \\
\hline & $\times$ Aeg. bicornis & $4^{2}$ & 5 & 6.3 & 5.5 \\
\hline \multirow{4}{*}{\multicolumn{2}{|c|}{$\begin{array}{l}\text { AMPHIPLOID HYBRIDS } \\
\text { T. aestivum var. April Bearded } \times \\
(T \text {. dicocoides } \times \text { Aeg. umbellulata }) \\
(T \text {. dicoccoides } \times \text { Aeg. umbellulata }) \times \\
(T \text {. dicoccoides } \times \text { Aeg. caudata })\end{array}$}} & & & & \\
\hline & & & $I$ & & \\
\hline & & $4-$ & & & 24 \\
\hline & & $4^{2}$ & I & $9 \mathrm{I}$ & $4 \cdot 4$ \\
\hline
\end{tabular}

amphiploids. These peaks in the $8 x$ diagram are, however, derived from only 2 out of 13 amphiploids with mosaics. There is thus a peak

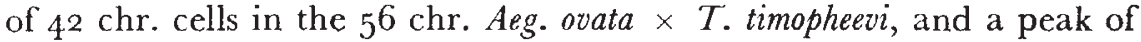
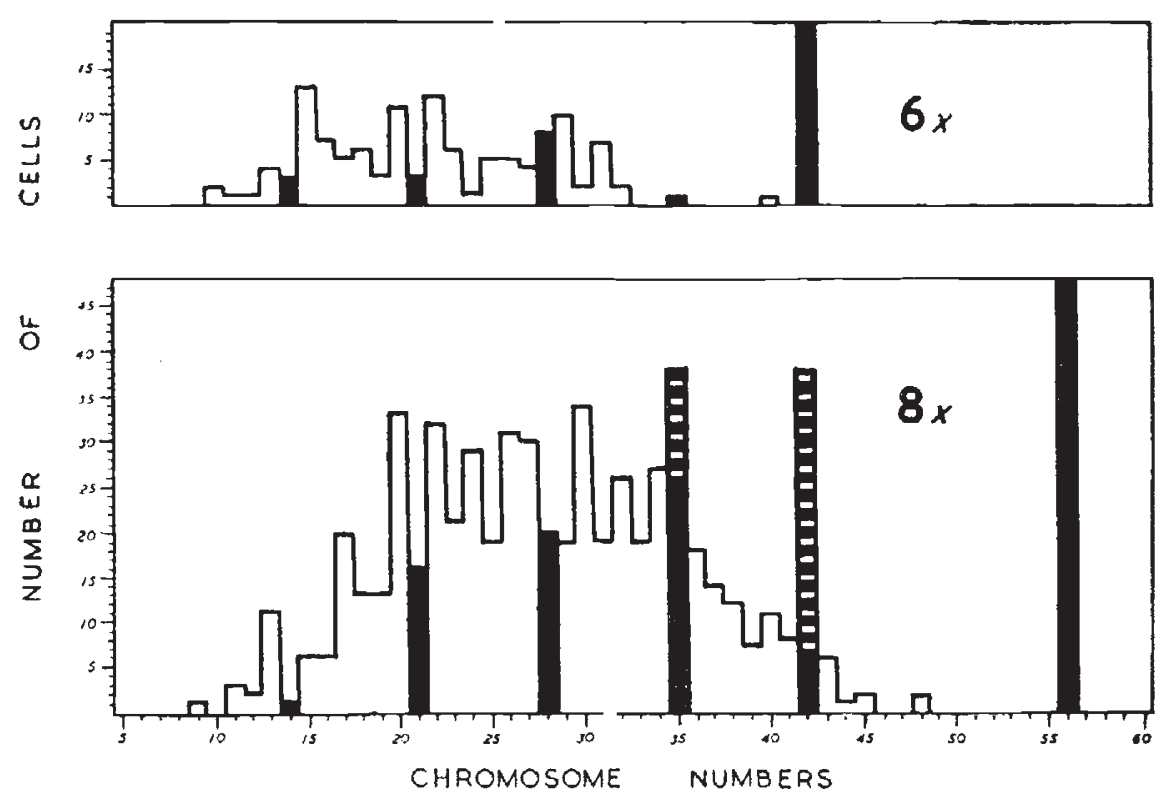

FIc, 1,-Diagrams of the frequencies of cells with different chromosome numbers.

Upper diagram - $6 x$ amphiploids.

Lower diagram - $8 x$ amphiploids.

Cross-hatching in $8 x$ diagram-the 35 anci 42 chr. cells from two particular plants with peak frecutencies. 
$35 \mathrm{chr}$. cells in the $56 \mathrm{chr}$. T. timopheevi $\times T$. durum. In addition to peaks occurring in only two out of the I 3 amphiploids, the 42 peak in Aeg. ovata $\times T$. timopheevi was found in only one of the three plants of this amphiploid and the 35 peak in $T$. timopheevi $\times T$. durum in only one of two plants. The peaks in these two plants may have been produced by earlier abnormalities than those occurring in the other plants.

Altogether there was a peak in the frequency of cells with a particular reduced chromosome number in only two out of forty-three plants with mosaics shown in table I. Thus 31 cells with 42 chrs. have been found in one plant, and 12 cells with 35 chrs. have been found in the other plant. These cells have been marked by crosshatching in the $8 x$ diagram (fig. I). If these 42 and $35 \mathrm{chr}$. cells, derived from the two plants, are not included in the $8 x$ totals, the diagram loses its peaks at 35 and 42 . There is thus, in general, no regularity in the formation of frequency peaks either in the $8 x$ or in the $6 x$ amphiploids.

\section{CHROMOSOME MOSAICS IN LATER GENERATION AMPHIPLOIDS AND THEIR HYBRIDS}

Chromosome mosaics at meiosis have also been found in later generation amphiploids. The amphiploids $T$. dicoccoides $\times$ Aeg. umbellulata and $T$. timopheevi $\times$ Aeg. bicornis were produced by MacFadden and Sears (1947) in I94I and 1942 respectively, and in addition to having been grown at Missouri, U.S.A., they have also been grown at Cambridge, England, for two further generations. It can be seen from table 2 that chromosome mosaics were found at meiosis in both these amphiploids.

In the amphiploids $T$. timopheevi $\times$ Aeg. bicornis mosaics at meiosis were found in 42 chromosome plants grown at Cambridge, England, in 1949 and 1950, and at Lund, Sweden, in 1951. With seeds which were also obtained from Dr E. R. Sears, Li and Tu (1947) found mosaics in this amphiploid in plants grown at Szechuan, China. Variation in chromosome number at meiosis has thus been observed in successive generations and under a range of environmental conditions. In addition to the two later generation amphiploids mentioned above, mosaics were also observed in a 42 chromosome plant of the later generation amphiploid $T$. timopheevi $\times$ Aeg. squarrosa.

The data in table 2 further shows that mosaics were found in a hybrid between the amphiploid $T$. dicoccoides $\times$ Aeg. umbellulata and a variety of $T$. aestivum.-No mosaics were found in hybrids between the amphiploid $T$. dicoccum $\times$ Aeg. caudata and four varieties of $T$. aestivum. The ability of the amphiploid $T$. dicoccoides $\times$ Aeg. umbellulata to produce a small percentage of cells with reduced chromosome numbers was thus also found in the hybrid with $T$. aestivum. No mosaics were found in the amphiploid $T$. dicoccum $\times$ Aeg. caudata and there were also no mosaics in the hybrids with $T$. aestivum. Cells with reduced chromosome numbers were also found in a hybrid between the amphiploid 
T. dicoccoides $\times$ Aeg. umbellulata and the amphiploid $T$. dicoccoides $\times$ Aeg. caudata. As in the new amphiploids, there is no regular formation of peaks in the frequency of cells with a particular reduced chromosome number. In the amphiploid T. timopheevi $\times$ Aeg. bicornis, a slight peak in the frequency of 15 chromosome cells was found but only in one of the five plants examined.

TABLE 3

Amphiploid Chromosome Pairing and the Percentage of Cells with Reduced Chromosome Numbers

\begin{tabular}{|c|c|c|c|c|c|c|c|}
\hline \multirow{2}{*}{\multicolumn{2}{|c|}{ AMPHIPLOIDS }} & \multicolumn{5}{|c|}{$\begin{array}{l}\text { Configurations in cells with } \\
\text { complete amphiploid } \\
\text { chromosome no. }\end{array}$} & \multirow{2}{*}{$\begin{array}{l}\text { Cells with } \\
\text { reduced } \\
\text { chromosome } \\
\text { nos. } \%\end{array}$} \\
\hline & & I & II & III & IV & V/VI & \\
\hline $\begin{array}{l}2 n=42 \\
\text { Aeg, cylindrica }\end{array}$ & & & & & & & \\
\hline $\begin{array}{l}\text { Aeg. cylinarica } \\
\text { Aeg caudata }\end{array}$ & $\begin{array}{l}\times 1 . \text { ooencum } \\
\times \text { T. dicoccoides }(\mathrm{b})\end{array}$ & $\begin{array}{l}1.52 \\
0.40\end{array}$ & $\begin{array}{l}20^{\circ} 24 \\
20^{\circ} 80\end{array}$ & - & - & 二 & 二 \\
\hline T. dicoccum & $\times$ Aeg. caudata & 0.12 & $20 \cdot 94$ & - & - & - & - \\
\hline Aeg. caudata & $\times \mathcal{T}$. dicoccum & 0.12 & 20.94 & - & - & - & $o \cdot x$ \\
\hline " & $\times \mathcal{T}_{\mathcal{T}} \cdot$ turgidum & 0.38 & $20 \cdot 66$ & 0.10 & - & - & $O \cdot I$ \\
\hline & $\times$ T. durum & 0.68 & $20 \cdot 60$ & 0.04 & - & - & 0.7 \\
\hline T. dicoccoides $(\mathrm{c})$ & $\times$ T. boeticum & $1 \cdot 48$ & 18.90 & 0.24 & 0.50 & - & ${ }^{1} \cdot 5$ \\
\hline Aeg. caudata & $\times$ T. timopheevi & $I \cdot 50$ & $20 \cdot 16$ & 0.06 & - & - & $3 \cdot 1$ \\
\hline Aeg. ovata & $\times$ T. boeticum & 0.44 & $20 \cdot 7^{8}$ & - & - & - & $3 \cdot 2$ \\
\hline \multicolumn{2}{|l|}{$2 n=5^{6}}$. & & & & & & \\
\hline Aeg. cylindrica & $\times$ T. carthlicum & 7.04 & $24 \cdot 48$ & 一 & - & - & $1 \cdot 2$ \\
\hline & $\times T \cdot$. & $6 \cdot 7^{6}$ & $24 \cdot 62$ & - & $-\overline{-6}$ & - & $2 \cdot I$ \\
\hline T. dicoccum & $\times$ T. timopheevi & $1 \cdot 04$ & 23.94 & $0 \cdot 24$ & $\begin{array}{l}1 \cdot 56 \\
-5\end{array}$ & 0.02 & 2.5 \\
\hline T. timopheevi & $\times$ T. turgidum & 0.92 & $24 \cdot 06$ & 0.18 & $I \cdot 5^{8}$ & $0 \cdot 02$ & $2 \cdot 6$ \\
\hline T. dicoccoides (b) & $\times$ T. timopheevi & $1 \cdot 48$ & $23 \cdot 28$ & 0.36 & $1 \cdot 72$ & - & $3 \cdot 4$ \\
\hline T. dicoccoides (a) & $\times \quad, \quad, \quad *$ & $I \cdot 47$ & $2 \pi \cdot 10$ & 0.47 & $2 \cdot 73$ & - & 3.8 \\
\hline T. timopheevi & $\times$ T.durum & I.70 & 23.18 & $0.3^{8}$ & $1 \cdot 70$ & - & $4 \cdot 8$ \\
\hline T. dicoccoides (a) & $\times$ Aeg. nvata & $3 \cdot 64$ & $26 \cdot 18$ & - & 二 & - & $6 \cdot 9$ \\
\hline Aeg. ovata & $\times T$ dicoccum & $4 \cdot 20$ & 25.90 & - & - & - & $8 \cdot 9$ \\
\hline & $\times$ T. timopheevi & $1 \cdot 50$ & $27 \cdot 20$ & 一 & - & - & ${ }^{14} \cdot{ }^{\prime} \cdot$ \\
\hline T. dicoccoides (c) & $\times$ Aeg. ovata & 0.60 & 27.70 & - & - & - & 14.5 \\
\hline $2 n=$ & & & & & & - & - \\
\hline & $\times$ Agr. interm & $1 \cdot 24$ & $34 \cdot 38$ & - & - & - & - \\
\hline
\end{tabular}

* 30 cells, in all others 50 cells analysed for chromosome pairing in each amphiploid.

\section{CHROMOSOME MOSAICS AND AMPHIPLOID PAIRING}

It has been shown in the previous sections that chromosome mosaics can be found at meiosis in the anthers of some amphiploids, and that different amphiploids show different percentages of cells with reduced chromosome numbers. An analysis of chromosome pairing at meiosis in cells with the complete amphiploid chromosome complement has shown that different amphiploids have different degrees of chromosome pairing. It is therefore of interest to determine if the presence of cells with reduced chromosome complements affects the chromosome pairing at meiosis in cells with the complete chromosome complement. Chromosome pairing in cells with the complete amphiploid chromosome complement has therefore been recorded in relation to the percentage of 
cells with reduced chromosome numbers. This is shown in table 3 .

A comparison of $2 \mathrm{r}$ different amphiploids shows that amphiploid chromosome pairing is not related to the presence or frequency of cells with reduced chromosome numbers. Chromosome pairing at meiosis in cells with the complete amphiploid chromosome complement is thus determined by the combination of parent species and varieties used in the production of the amphiploid.

\section{PAIRING IN CELLS WITH A REDUCED COMPLEMENT}

A high univalent frequency is characteristic of cells with a reduced chromosome complement. It is found independently of the presence of univalents in cells with the complete amphiploid chromosome complement. If, however, multivalents are formed in cells with the complete amphiploid complement, multivalents also occur in some cells with a reduced complement. Pairing has been studied in all the cells with reduced chromosome complements, and this has shown a wide variation in their constitution. Some representative data on pairing is given in table 4 .

\section{TABLE 4}

Chromosome Pairing in Cells with Reduced Chromosome Numbers

\begin{tabular}{|c|c|c|c|c|c|c|c|c|}
\hline \multicolumn{5}{|c|}{$\begin{array}{c}\text { SPECIES HYBRID } \\
6 \times T \text {. dicoccoides (c) } \times T \text {. boeticum }\end{array}$} & \multicolumn{4}{|c|}{$\begin{array}{c}\text { GENUS HYBRID } \\
8 \times T \text {. dicoccoides }(\mathrm{c}) \times \text { Aeg. ovata }\end{array}$} \\
\hline \multirow{2}{*}{$\begin{array}{l}\text { Chr. no. } \\
\text { of cell }\end{array}$} & \multicolumn{3}{|c|}{ Chromosome pairing } & \multirow{2}{*}{$\begin{array}{l}\text { Fre- } \\
\text { quency }\end{array}$} & \multirow{2}{*}{$\begin{array}{l}\text { Chr. no. } \\
\text { of cell }\end{array}$} & \multicolumn{2}{|c|}{ Chromosome pairing } & \multirow{2}{*}{$\begin{array}{c}\text { Fre- } \\
\text { quency }\end{array}$} \\
\hline & I & II & III & & & I & II & \\
\hline I0 & 10 & - & - & $I$ & IX & II & 一 & $I$ \\
\hline II & 9 & 1 & 一 & $I$ & 13 & II & I & $I$ \\
\hline 13 & 7 & 3 & - & $I$ & 17 & 15 & I & 3 \\
\hline 15 & II & 2 & - & 2 & , & 13 & 2 & 2 \\
\hline 16 & Io & 3 & - & 2 & 20 & 14 & 3 & 3 \\
\hline 17 & II & 3 & - & $I$ & " & I0 & 5 & 2 \\
\hline 20 & 8 & 6 & - & 3 & 21 & 13 & 4 & $I$ \\
\hline , & 7 & 5 & $I$ & $I$ & 23 & I 3 & 5 & $I$ \\
\hline 21 & 7 & 7 & - & $I$ & 28 & 14 & 7 & $I$ \\
\hline 22 & 12 & 5 & 一 & $I$ & , & 12 & 8 & 2 \\
\hline$\eta$ & 7 & 6 & $I$ & $I$ & " & 8 & Io & 2 \\
\hline 23 & 5 & 9 & - & $I$ & 35 & I 5 & Io & 2 \\
\hline 31 & 9 & I I & - & $I$ & 42 & 14 & 12 & 2 \\
\hline
\end{tabular}

The general absence of frequency peaks at particular chromosome numbers in the mosaics and their high univalent frequency indicates that the reduced numbers represent an almost random assortment of chromosomes. This could have been produced by pre-meiotic spindle abnormalities. Chromosome pairing at meiosis in undoubled $\mathrm{F}_{\mathrm{I}}$ hybrids and in complete amphiploid cells has shown a greater pairing affinity between chromosomes in the interspecific hybrids than in the intergeneric hybrids. A random assortment of chromosomes in the interspecific amphiploids should thus show a greater degree of pairing than in the intergeneric amphiploids. These different degrees of chromo- 
some pairing are in fact shown in table 4 . Thus in the same plant meiosis can take place in cells which differ widely in their chromosome constitution.

\section{THE SURVIVAL OF ABERRANT GAMETES}

The present data on the survival of aberrant gametes is based on the chromosome constitution of I 2 first generation amphiploid plants. The complete amphiploid number is 42 for the plants in table 5, and 56 for those in table 6 . The chromosome constitutions of these plants were determined at $M_{1}$ of meiosis. It can be seen from table 5 that out of a total of 36 plants, $16.7 \%$ had less than 42 chromosomes, and there was one plant with 43 chromosomes. The existence of subamphiploid numbers shows that, with a slight reduction in chromosome number, these amphiploids may still produce functional gametes. Comparable data for differcnt amphiploids in the Triticinae have also been given by MacFadden and Sears (1947) and others. The survival of gametes with a reduced chromosome complement is further seen in table 6 where 66 plants gave $33.3 \%$ with a sub-amphiploid chromosome number.

TABLE 5

Chromosome Numbers of First Generation Plants whose Complete Amphiploid Chromosome Number would be $4^{2}$

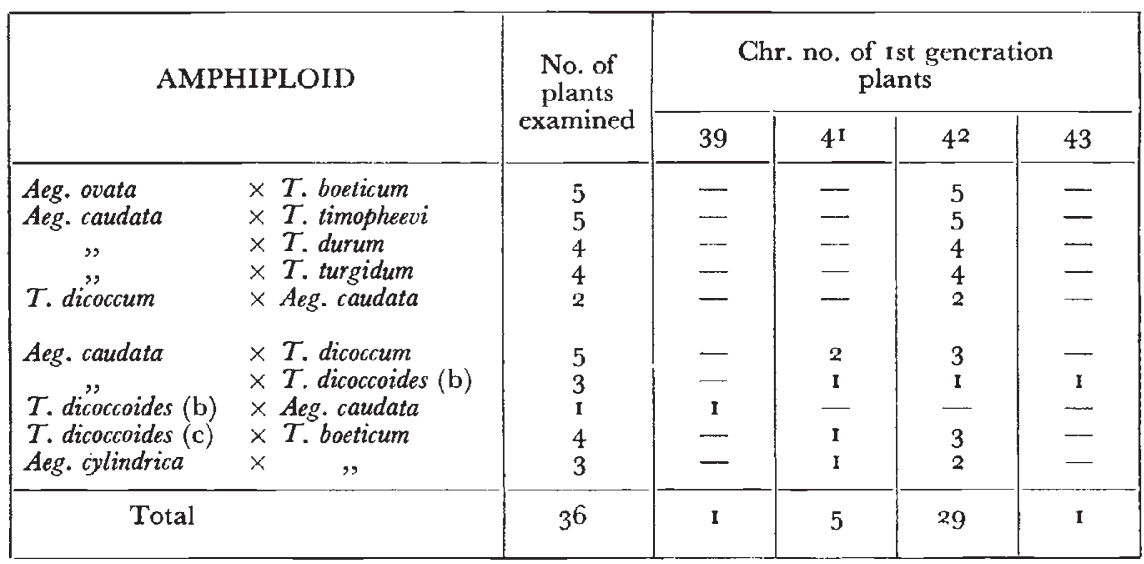

Of particular intcrest, however, are the $28,44,48$, and one of the 54 chromosome plants. The 28 plants derived from $\mathcal{T}$. timopheevi $\times$ $\mathcal{T}$. turanicum is comparable both in chromosome number and in chromosome pairing to its 28 chromosome $F_{1}$ hybrid. In this plant, haploid parthenogenesis (cf. Darlington, 1937) may have restored the original $F_{1}$ balance. In this 28 -chromosome plant with the original $F_{1}$ balance and number, I find there are no longer any mosaics in the anthers.

The four plants in table 7 have also been derived from 28 chromosome $F_{1}$ plants, but they show a marked deviation in number and pairing both from the $\mathrm{F}_{1}$ hybrid and the expected amphiploids. These 
TABLE 6

Chromosome Numbers of First Generation Plants whose Complete Amphiploid Chromosome Number would be 56

\begin{tabular}{|c|c|c|c|c|c|c|c|c|c|}
\hline \multicolumn{2}{|c|}{ AMPHIPLOID } & \multirow{2}{*}{$\mid \begin{array}{c}\text { No. of } \\
\text { plants } \\
\text { examined }\end{array}$} & \multicolumn{7}{|c|}{$\begin{array}{c}\text { Chr. no. of Ist generation } \\
\text { plants }\end{array}$} \\
\hline & & & 28 & 44 & $4^{8}$ & 54 & 55 & $5^{6}$ & 57 \\
\hline T. dicoccoides (a) & $\times$ Aeg. ovata & 5 & - & - & - & - & - & 5 & - \\
\hline Aeg. cylindrica & $\times T$. durum & 3 & - & - & - & - & - & 3 & - \\
\hline T. dicoccoides (a) & $\times$ T. timpopheevi & 4 & - & - & - & - & - & 4 & - \\
\hline T. turgidum & $\times \quad$, & 3 & 一 & - & - & - & 一 & 3 & 一 \\
\hline T. timopheevi & $\times$ T. turgidum & 2 & - & - & 一 & - & - & 2 & - \\
\hline , & $\times T \cdot$ polonicum & 2 & 一 & 一 & 一 & 一 & - & 2 & 一 \\
\hline T. timopheevi & $\times T$. durum & 3 & - & - & 一 & - & I & 2 & 一 \\
\hline$T$. dicoccum & $\times$ T. timopheevi & 6 & - & - & 一 & 一 & $\mathbf{I}$ & 4 & $\mathbf{I}$ \\
\hline T. dicoccoides (b) & $\times \quad$, & 4 & - & 一 & - & - & $\mathbf{I}$ & 3 & 一 \\
\hline Aeg. cylindrica & $\times$ T. carthlicum & 3 & - & - & 一 & - & I & 2 & 一 \\
\hline r., & $\times T \cdot$ dicoccum & 4 & - & - & - & 2 & 2 & -- & - \\
\hline T. dicoccoides $(\mathrm{c})$ & $\times$ Aeg. ovata & 5 & - & - & - & $\mathbf{I}$ & $\mathbf{I}$ & 3 & - \\
\hline Aeg. ovata & $\times$ T. timopheevi & 4 & - & - & - & $\mathbf{1}$ & 一 & 3 & 一 \\
\hline ", & $\times T$. dicoccum & 4 & - & - & 一 & - & 1 & 3 & 一 \\
\hline & $\times T$. dicoccoides $(\mathrm{b})$ & 1 & - & $\mathbf{r}^{*}$ & - & - & - & -- & 一 \\
\hline T. dicoccum & $\times$ Aeg. ovata & 4 & - & - & $\mathbf{I *}^{*}$ & 2 & $\mathbf{I}$ & - & 一 \\
\hline T. timopheevi & $\times \quad$, & 5 & - & - & $\mathbf{r}^{*}$ & 一 & 2 & 2 & 一 \\
\hline T. durum & $\times$ & 2 & 一 & - & - & $\mathbf{I}^{*}$ & - & r & - \\
\hline T. timopheevi & $\times T \cdot$ turanicum & 2 & $\mathbf{I}$ & - & - & - & 一 & I & - \\
\hline \multicolumn{2}{|l|}{ Total } & 66 & 1 & 1 & 2 & 7 & I I & 43 & $\mathbf{I}$ \\
\hline
\end{tabular}

* - data on chromosome pairing in these plants in given in table 7

plants are characterised by a high univalent frequency, and they must have been derived from the fusion of gametes with deviating chromosome complements. Nevertheless, mosaics at meiosis have been found in these 44,48 , and 54 chromosome plants. These mosaics in the anthers are similar to those which have been described for the amphiploid plants.

The origin and union of similar types of aberrant gametes would explain the occurrence of plants with an abnormal chromosome constitution such as those reported in Triticum-Agropyron hybrids (Love and Suneson, 1945).

TABLE 7

Chromosome Pairing in Aneuploid Plants derived from Reduced Cells in the Mosaics

\begin{tabular}{|c|c|c|c|c|c|c|}
\hline \multirow{2}{*}{\multicolumn{2}{|c|}{$8 x$ PARENTS }} & \multirow{2}{*}{$\begin{array}{l}\text { Approx. no } \\
\text { of I per cell } \\
\text { in } 8 x \text { parent }\end{array}$} & \multirow{2}{*}{$\begin{array}{l}\text { Aneu- } \\
\text { ploid } \\
\text { chr. no. }\end{array}$} & \multicolumn{3}{|c|}{$\begin{array}{l}\text { Chromosome pairing } \\
\text { Aneuploids }\end{array}$} \\
\hline & & & & I & II & III \\
\hline $\begin{array}{l}\text { Aeg ovata } \\
\text { T. dicoccum } \\
\text { T. timopheevi } \\
\text { T. durum }\end{array}$ & $\begin{array}{l}\times T \text {. dicoccoides }(\mathrm{b}) \\
\times \text { Aeg ovata } \\
\times \text { Aeg. ovata } \\
\times \text { Aeg. ovata }\end{array}$ & $\begin{array}{l}0 \cdot 6 \\
4 \cdot 2 \\
1 \cdot 5 \\
2 \cdot 8\end{array}$ & $\begin{array}{l}44 \\
48 \\
48 \\
54\end{array}$ & $\begin{array}{l}26 \cdot 04 \\
19 \cdot 44 \\
25 \cdot 62 \\
16 \cdot 44\end{array}$ & $\begin{array}{r}8 \cdot 98 \\
\mathbf{4} \cdot 28 \\
9 \cdot 66 \\
17 \cdot 40\end{array}$ & $\begin{array}{l}- \\
\bar{I} \cdot 02 \\
0.92\end{array}$ \\
\hline
\end{tabular}

50 cells analysed in each aneuploid plant 
In the present investigation the plants with an aberrant chromosome constitution (table 7) were sterile. This sterility resulted from a high univalent frequency. Owing to the almost random assortment of chromosomes in the cells at meiosis, the same sterility would be expccted in many plants produced in a similar manner. In annual sexually reproducing plants, where perpetuation in nature is dependent upon sexual reproduction, many of these abnormal constitutions would be unable to survive on account of their sterility. In perennial plants, the abnormal constitution could survive in nature despite sterility. The survival of these plants with varying chromosome constitution could ensure the production of gametes with a further deviation from the original chromosome condition. Thus the four plants with an abnormal constitution were still able to produce mosaics at meiosis. In perennial plants, therefore, a similar mechanism could in time produce an cxtensive range of aneuploidy and a reduction of chromosome number in phylogeny. A vcry extensive ancuploid scries has in fact been found in some plant genera (Stebbins, 1950, table VIII). The mechanism of chromosome variation described above could thus explain the origin and establishment of some of these aneuploid series which have been found to occur in nature.

\section{DISCUSSION}

\section{(a) The Origin of Chromosome Mosaics}

The present investigation has shown that cells with reduced chromosome numbers can be found at meiosis in certain amphiploids. These chromosome mosaics at meiosis were not found either in the parent species or in the $F_{1}$ hybrids from which the amphiploids were produced. They were also not found in all amphiploids. No mosaics were found in the yo chromosome anthers, the highest chromosome number amphiploid which was examined. The existence of mosaics was therefore not dependent merely upon the magnitude of the chromosome number of the amphiploids.

It has further been shown that the capacity to form mosacis can be transmitted to successive generations. All amphiploids in the present investigation were produced by the colchicine treatment of $F_{1}$ hybrid plants. The mosaics at meiosis in the present study can however not be attributed to a pcrmanent effect of colchicine such as that suggested by Vaarama (1949a) in Ribes nigrum. Cells with reduced chromosome numbers at meiosis have occasionally been observed in other Triticum hybrids which had not been treated with colchicine (Hollingshead, 1932; Love, 1938) and in a Triticum-Secale hybrid which was also produced without colchicine (Katterman, 1933). A more probable explanation, therefore, is that the mosaics depend on certain gene combinations.

Cells with reduced chromosome numbers have been found at the early stages of meiosis. The mosaics must therefore have been produced by irregularities at the pre-meiotic cell divisions. The different 
chromosome numbers at meiosis could have been produced by spindle abnormalities, such as multipolar spindles, during these pre-meiotic cell divisions. That certain gene combinations can cause split spindles has been established both for mitosis and meiosis. Darlington and Thomas (I 937) have shown that abnormal spindles at meiosis can occur in a hybrid derivative of Festuca-Lolium. Spindle abnormalities at meiosis can be determined by single gene differences (Smith, r942). Certain gene combinations can produce multipolar spindles at mitosis (Vaarama, I949b). The genetic control of spindle abnormalities at mitosis would explain the distribution and transmission of chromosome mosaics in amphiploids. As different amphiploids possess different gene combinations, this would explain the presence of mosaics in some and their absence in others. In addition, the genotype of an amphiploid differs from that in its $F_{1}$ hybrid and its parent species. The absence of mosaics in parent species and the $F_{1}$ hybrids and their presence in an amphiploid are thus a reflection of the differences in their genotypes. The occurrence of cells with reduced chromosome numbers at meiosis in one strain of autotetraploid rye (O'Mara, I942), and the absence of these cells in another strain of autotetraploid rye (Müntzing, I95I), may also be due to the difference in their genic combinations.

The distribution at meiosis of cells with reduced chromosome numbers can give some indication of the time at which earlier disturbances have taken place. In amphiploids with mosaics, the cells with reduced numbers occurred at meiosis, either in small groups, or singly-even in the same anther. In addition, the reduced cells were not localised in any particular position in the anthers. It has been pointed out above that in the anthers with mosaics the majority of cells still contain the non-reduced number, which was constant for each plant in all its anthers. There was thus no case of a chromosome chimaera between different anthers of the same plant. Moreover there were no mosaics at mitosis in the root tips in plants with mosaics at meiosis. All these things indicate that the mitotic irregularities must have occurred late in the development of the plant. They could thus have been produced in the cell generations just preceding meiosis.

The cell divisions immediately preceding meiosis may in fact be different from the mitosis occurring at other stages in ontogeny. A precocity theory of meiosis has been suggested by Darlington (I937, 1939). According to this theory, the external changes outside the chromosomes are precocious at meiosis. Oksala (1944) has concluded that precocity in the dragonfly Aeschna juncea, is gradually developed and can be observed in at least two cell divisions preceding meiosis. Mitosis in cells with this developing precocity is therefore different from mitosis in other cells. Mitotic abnormalities may thus occur during these pre-meiotic cell divisions although they do not occur at other stages of ontogeny. However not all gene combinations producing mitotic abnormalities only function at a late stage in ontogeny. Other 
gene combinations, such as those in tetraploid Ribes nigrum (Vaarama, r $949 b$ ) produce mitotic abnormalities resulting in different chromosome numbers in the root tips. Similar mitotic abnormalities can therefore be produced by different gene combinations at different stages in ontogeny.

In the present study there has been no evidence of chromosome pairing and segregation in somatic tissues. Huskins (r949) has however suggested that cells with reduced chromosome numbers can be produced by somatic chromosome pairing and segregation. But his cited evidence in plants cannot be considered as conclusive. The recent evidence on "somatic reduction" in some Gossypium hybrids (Menzel and Brown, I952) can also be explained if the hybrid genotypes produce multipolar spindles. I have attempted to confirm the induction of "somatic meiosis" and "chiasma formation" in somatic tissues by treatment with sodium ribose nucleate. Root tips of Allium cepa and Triticum monococcum were treated with sodium salts of both ribose and deoxyribose nucleic acid in various concentrations. These have shown no evidence for a "somatic meiosis". It must therefore be concluded that somatic chromosome pairing and segregation in plants has not yet been cytologically demonstrated.

\section{(b) Aneuploid Variation within the Tissue}

The existence of aneuploid variation in the same tissue shows that cells with a considerable deviation from the full chromosome complement are still able to divide. In the amphiploids examined, cells containing a variety of different chromosome numbers were able to undergo meiosis in the same plant. The greatest difference observed was the existence of 9 and 56 chromosome cells at meiosis in the same anther. The division of these cells at meiosis was almost completely synchronised so that the cells with different chromosome numbers are undergoing meiosis at the same time.

The synchronisation of the different cells at meiosis can be understood if the initiation of the process of meiosis is connected with the diffusion of certain substances. Montalenti et al. (1950) have suggested that in the testis of Asellus aquaticus, ribose nucleic acid secreted from outside the germ cells is casually connected with the beginning of meiosis. In this connexion it is of interest that the secretory cells in Asellus, which surround the cells undergoing meiosis, are polyploid. In plants the tapetum, which surrounds the cells undergoing meiosis, also contains polyploid cells (Brown, r949). In the present study it has been observed that the tapetal cells have only one nucleus before the beginning of meiosis, but that the tapetal cells are binucleate during meiosis. The polyploid tapetal cells may thus fulfil the same secretory function in the anthers which has been attributed to the polyploid secretory cells of the testis in Asellus.

The simultaneous initiation of meiosis in the cells with different chromosome numbers, connected with the diffusion of certain sub- 
Microphotographs of Pollen mother cells at Metaphase I.

Feulgen stained $\times$ I Ioo.

I. $6 x$ Aeg. ovala $\times$ T. boeticum

I 4 chromosome cell in $42 \mathrm{chr}$. plant.

6 I 4 II

3. $8 x$ Aeg. ovata $\times$ T. dicoccum

I 6 chromosome cell in $56 \mathrm{chr}$. plant.

I 2 I 2 II

2. $6 x$ T. timopheevi $\times$ Aeg. bicornis

22 chromosome cell in $42 \mathrm{chr}$. plant.

I 2 I 5 II

4. $8 x$ Aeg. ovata $\times$ T. dicoccum

40 chromosome cell in $56 \mathrm{chr}$. plant.

I2 I I4 II

5. $6 x$ Aeg. caudata $\times$ T. turgidum

42 chromosome cell in $42 \mathrm{chr}$. plant.

3 I I 8 II I III

6. $8 \times$ Aeg. orata $\times$ T. timopheevi $5^{6}$ chromosome cell in $56 \mathrm{chr}$. plant . 4 I 26 II 

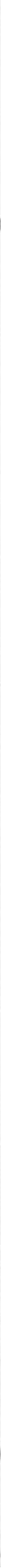
stances, can thus account for the ability of the aneuploid cells to undergo meiosis. The diffusion of certain substances can also account for the ability of the aneuploid cells to undergo mitosis. Another cause of the survival of aneuploid cells in the amphiploids is that the derived polyploid origin of the plants concerned may have been connected with a greater ability to tolerate the loss of chromosomes. In addition, different plant species may show different degrees of chromosome differentiation (Darlington and Mather, I944).

In animals also, different species may differ in the physiological differentiation of their chromosomes. In addition, animal tissues with no proper cell wall present considerable possibilities for the diffusion of substances between different cells. The diffusion of substances between the different cells could thus account for the high viability of aneuploid numbers which have been found in certain human tissues (Therman and Timonen, I95I).

The available data on aneuploid variation in the same tissue is, however, still very small. A further study of the development and extent of this chromosome variation, and of the possible substances involved in cell survival, would greatly contribute to an understanding of the processes of growth, development, and differentiation.

\section{SUMMARY}

I. Chromosome mosaics at meiosis arise in the anthers of I9 out of 24 new amphiploids in Triticum, Aegilops, and Agropyron.

2. The mosaics occurred in all the $8 x$, in some of the $6 x$, but not in a ro $x$ amphiploid.

3. The anthers with mosaics contain at meiosis a mixture of cells with complete amphiploid and various reduced aneuploid numbers.

4. 37 reduced chromosome numbers, from 9 to 48 , were found in the $8 x$ amphiploids, and 24 reduced numbers, from io to 40 , in the $6 x$ amphiploids. 27 numbers at meiosis occurred in a single $8 x$ plant, and Io numbers at meiosis in a single $6 x$ plant.

5. There was no relationship between the presence of mosaics and chromosome pairing in those cells which have retained a complete chromosome complement.

6. The reduced cells in mosaic plants represent at meiosis an almost random assortment of chromosomes. Mosaics probably arise by genecontrolled spindle abnormalities just before meiosis.

7. Plants bred true for mosaic formation. Moreover, reduced cells in mosaic plants can function as gametes. Their progeny can again produce mosaics. A range of chromosome numbers can thus be derived from the same amphiploid.

Acknowledgments. - I am indebted to Dr C. D. Darlington for his advice and assistance with the manuscript. The experimental work was mainly carried out at Cambridge, and I wish to thank Dr G. D. H. Bell for his constant interest. 


\section{REFERENCES}

Brown, s. w. 1949. Endomitosis in the tapetum of tomato. Amer. Four. Bot., 36, 703-716.

Darlington, c. D. 1937. Recent Advances in Cytology, 2nd edition. Churchill, London.

Darlington, c. D. 1939. The Evolution of Genetic Systems. The University Press, Cambridge.

DARLington, C. D., AND MATher, K. 1944. Chromosome balance and interaction in Hyacinths. 7. Genet., 46, 52-61.

DARLington, c. D., AND ThOMAS, P. T. 1937. The breakdown of cell division in a Festuca-Lolium derivative. Ann. Bot. $\mathcal{N} . S .$, r, 747-76r.

FANKHAUSER, G. 1945. The effects of changes in chromosome number on amphibian development. Quart. Rev. Biol., 2, 20-78.

HOLLINGSHEAD, L. 1932. The occurrence of unpaircd chromosomes in hybrids bctwccn varieties of Triticum vulgare. Cytologia, 3, I 19-141.

Huskins, c. L. 1949. The nucleus in devclopment and differentiation and the experimental induction of "meiosis". Proc. 8th Int. Genet. Congress (Stockholm), $274-285$.

KatreRMANN G. 1933. Eih Beitrag zur Frage der Dualität der Bcstandteile des Bastardkernes. Planta, $18,75 \mathrm{I}-785$.

LI, H. W., AND TU, D. s. 1947. Studies on the chromosomal aberrations of the amphiploid Triticum timopheevi and Aegilops bicornis. Bot. Bul. Acad. Sinica, r, 173-186.

LOVE, R. M. 1938. Somatic variation of chromosome numbers in hybrid wheats. Genetics, 23, 51 7-522.

LOVE, R. M., AND SUNESON, c. A. 1945. Cytogenetics of ccrtain Triticum-Agropyron hybrids and their fertilc derivatives. Amer. Jour. Bot., 32, 45 I-456.

MACFADDEN, E. S., AND SEARs, E. R. 1947. The genome approach to radical wheat brccding. 7. Amer. Soc. Agron., 39, 101 1-1026.

MENZEL, M. V., AND BROWN, D. S. 1952. Polygenomic hybrids in Gossypium II Mosaic formation and somatic reduction. Amer. Jour. Bot., 39, 59-69.

montalenti, G., et al. 1950. The supply of ribonucleic acid to the malc germ cells during meiosis in Asellus aquaticus. Heredity, 4, 75-87.

MÜNTLING, A. 195I. Cytogenetic properties and practical value of tetraploid rye. Hereditas, 37, 1 7-84.

oksala, T. 1944. Zytologische Studien an Odonaten II Die Enstehung der Meiotischen Präkozität. Ann. Acad. Sci. Fennicae, A. IV 5, 1-33.

o'mara, J. G. 1942. Meiosis in autotetraploid Secale cereale. Bol. Gaz., 104, 563-575. SACHS, LEO. 1952. Chromosome behaviour in species hybrids with Triticum timopheevi. Heredity (in press).

smirh, L. 1942. Cytogenetics of a factor for multiploid sporocytes in barley. Amer. Four. Bot., 29, $45^{1-45^{6}}$.

STEBbins, G. L., JR. 1950. Variation and Evolution in Plants. Columbia University Press, New York.

THERMAN, E., AND TIMONEN, s. I95 I. Inconsistency of the human somatic chromosome complement. Hereditas, 37, 266-279.

vanrama, A. 1949a. Permanent effect of colchicinc on Ribes nigrum. Proc. 8th Int. Genet. Congress (Stockholm), 680-681.

vaArama, A. I 9496 . Spindle abnormalitics and variation in chromosome number in Ribes nigrum. Hereditas, $35,136-162$. 